\title{
The Initial Phase of a Longleaf Pine-Wiregrass Savanna Restoration: Species Establishment and Community Responses
}

\author{
Todd A. Aschenbach, ${ }^{1,2,3}$ Bryan L. Foster ${ }^{1}$ and Donald W. Imm ${ }^{4}$
}

\begin{abstract}
The significant loss of the longleaf pine-wiregrass ecosystem in the southeastern United States has serious implications for biodiversity and ecosystem functioning. In response to this loss, we have initiated a long-term and landscape-scale restoration experiment at the 80,125 ha $\left(310 \mathrm{mi}^{2}\right)$ Department of Energy Savannah River Site (SRS) located near Aiken, South Carolina. Aristida beyrichiana (wiregrass), an important and dominant grass (i.e., a "matrix" species) of the longleaf pine savanna understory, and 31 other herbaceous "non-matrix" species were planted at six locations throughout SRS in 2002 and 2003. Of the 36,056 transplanted seedlings, $75 \%$ were still alive in June 2004, while mean 1-2 year survival across all planted species was $48 \%$. Lespedeza hirta (hairy lespedeza) exhibited the greatest overall survival per $3 \times 3 \mathrm{~m}$
\end{abstract}

cell at $95 \%$, whereas Schizachyrium spp. (little bluestem) exhibited the greatest mean cover among individual species at $5.9 \%$. Wiregrass survival and cover were significantly reduced when planted with non-matrix species. Aggregate cover of all planted species in restored cells averaged $25.9 \%$ in 2006. High rates of survival and growth of the planted species resulted in greater species richness (SR), diversity, and vegetative cover in restored cells. Results suggest that the loss of the longleaf pine-wiregrass ecosystem may be ameliorated through restoration efforts and illustrate the positive impact of restoration plantings on biodiversity and vegetative cover.

Key words: Aristida beyrichiana, longleaf pine savanna, restoration, Savannah River Site, wiregrass.

\section{Introduction}

Ecosystems dominated by Pinus palustris (longleaf pine) covered approximately 37 million ha throughout the southeastern United States prior to European settlement (Frost 1993). However, historical and continued losses due to logging and agricultural conversion, suppression of naturally occurring fires, and urbanization (Frost 1993; Ware et al. 1993) have reduced the original extent of longleaf pine ecosystems by $97 \%$ to approximately 1.3 million ha (Frost 1993), including only 4000 ha of old growth forest (Means 1996). These declines have surpassed those of other major ecosystems in the United States such as wetlands and have made the longleaf pine ecosystem one of the most endangered ecosystems in the United States (Noss et al. 1995).

\footnotetext{
${ }^{1}$ Department of Ecology and Evolutionary Biology, University of Kansas, Lawrence, KS 66045, U.S.A.

2 Address correspondence to T. A. Aschenbach, email aschenbt@gvsu.edu

${ }^{3}$ Present address: Natural Resources Management Program, Department of

Biology, Grand Valley State University, Allendale, MI 49401, U.S.A.

${ }^{4}$ Savannah River Ecology Laboratory, P.O. Box Drawer E, Aiken, SC 29802 ,

U.S.A.

(C) 2009 Society for Ecological Restoration International

doi: 10.1111/j.1526-100X.2009.00541.x
}

Communities dominated by longleaf pine include forests, woodlands, and savannas and occur on a variety of sites ranging from xeric sandhills to seasonally wet flatwoods (Platt et al. 1989; Harcombe et al. 1993; Peet \& Allard 1993). Regardless of the specific type of community considered, the disappearance of the longleaf pine ecosystem from the landscape has serious implications for biodiversity conservation and ecosystem functioning in the southeastern United States. Longleaf pine ecosystems contain some of the greatest plant species richness in temperate North America and include a large number of rare plant species (Walker \& Peet 1983; Hardin \& White 1989; Peet \& Allard 1993; Walker 1993). Longleaf pine ecosystems also provide critical habitat for rare species such as Picoides borealis (red-cockaded woodpecker) (Johnston 2005) and Gopherus polyphemus (gopher tortoise) (Buhlmann et al. 2005) and provide for important ecosystem functions and services (Mitchell et al. 1999; Markewitz et al. 2002).

The loss of the longleaf pine savanna ecosystem has generated considerable interest in the restoration of this ecosystem in the southeastern United States (Noss et al. 1995; Van Lear et al. 2005). In longleaf pine savanna, most restoration attempts have focused on two important and interconnected components: the return of fire and the reestablishment of Aristida beyrichiana Trin. \& Rupr. and A. stricta Michx. 


\section{DE- AI09-00SR22188 JOURNAL ARTICLE $2010 \quad 10-15-P$}

(wiregrass). Periodic fires help exclude invasive plant species (Reinhart \& Menges 2004), prepare a seedbed for the regeneration of longleaf (Wade \& Lundsford 1990), increase understory diversity (Walker \& Peet 1983; Rodgers \& Provencher 1999; Hedman et al. 2000; Reinhart \& Menges 2004), stimulate seed production of native species (Outcalt 1994), and cycle nutrients in these relatively infertile soils (McKee 1982). Wiregrass, a dominant species in the understory of longleaf pine ecosystems, helps regulate floristic composition through its ability to act as a fuel source for prescribed and natural fires and is therefore considered a keystone component of longleaf savanna (Clewell 1989; Noss 1989; Platt et al. 1989).

In order for restoration to be an effective tool for biodiversity and ecosystem conservation, spatially extensive and longterm reestablishment efforts in degraded landscapes are needed (Zedler 1996; Bell et al. 1997). Although most naturally occurring longleaf stands have been destroyed, extensive areas of longleaf pine have been replanted on abandoned agricultural fields and cutover lands in the southeast United States (Outcalt \& Sheffield 1996). Plantations may represent the greatest potential for practical long-term and large-scale longleaf pine ecosystem restoration (Hedman et al. 2000).

Here we report the initial results of a long-term experimental study established in 2001 at the Department of Energy Savannah River Site (SRS) in South Carolina to evaluate the potential for restoring the herbaceous understory component of the longleaf pine savanna. The study involves intensive site preparations and diverse native plantings at six sites, spanning a variety of soil conditions at SRS (xeric-mesic). Each of the six restoration sites are established in longleaf pine plantations at SRS that had been planted on former agricultural lands.

Information on the establishment of native plant populations is a research priority in the restoration of the longleaf pine ecosystem (Duever 1989; Van Lear et al. 2005) and successful restoration efforts require overcoming the various forms of resistance to natural recovery of the system (Suding et al. 2004). The inability of plant propagules to disperse to a site due to the cumulative effect of anthropogenic disturbance regionally (habitat loss/change, habitat fragmentation, etc.) and subsequent loss of native regional propagule pools (Zobel 1997; Foster 2001) can place strong constraints on local plant colonization rate, species composition and diversity at the local scale. Seed limitation is likely acute at SRS due to an absence of species in the available propagule pool. In this experiment, constraints imposed by the species pool were circumvented at each site by the transplantation of seedlings. A long-term aim of our study design is to evaluate the extent to which our intensively restored populations and sites may serve as a seed source for the larger landscape.

High tree densities and a dense shrub layer, resulting from fire suppression, reduces the availability of light and soil resources to the herb-layer, imparting strong competitive resistance to natural recruitment of native savanna plants (Harrington \& Edwards 1999; Mulligan et al. 2002; Platt et al. 2006). In this experiment, biotic resistance to native species establishment was ameliorated by thinning overstory tree densities to levels more typical of open savanna, instituting prescribed fire to maintain appropriate tree and shrub densities, herbiciding competing understory vegetation prior to transplantation, and irrigating transplants to facilitate initial establishment.

Although wiregrass may facilitate the persistence of fireadapted species, it may also act as a strong competitor with other herbaceous species thus potentially exerting a complex mix of facilitative and inhibitive impacts on the rest of the native plant component. Conversely, other herbaceous species may inhibit or facilitate the establishment of wiregrass.

Our study incorporates experimental planting manipulations that will elucidate biotic interactions relevant to the shortand long-term restoration of longleaf pine savanna. Here we provide the first detailed description of our study design and address the following objectives:

(1) To evaluate the initial effectiveness of our site preparation and planting methods in establishing populations of native understory savanna plants across a range of sites.

(2) To evaluate biotic interactions, including facilitation, competitive interference or some balance of both, between wiregrass and other species and the resulting effects on community assembly and diversity.

\section{Methods \\ Study Area}

This study was conducted at the 80,125 ha $\left(310 \mathrm{mi}^{2}\right)$, U.S. Department of Energy Savannah River Site (SRS), a National Environmental Research Park, in Barnwell and Aiken Counties, South Carolina, United States (lat $33^{\circ} 15^{\prime} \mathrm{N}$, long $\left.81^{\circ} 33^{\prime} \mathrm{W}\right)$. The climate of the area is characterized by $17.9^{\circ} \mathrm{C}$ mean annual temperature, and $121.4 \mathrm{~cm}$ of annual precipitation (Rogers 1990). Six sites were selected to represent a variety of edaphic conditions and soil fertilities present in the SRS landscape. Each of the six sites support stands of 30-50 year old longleaf pines that had been planted on abandoned agricultural lands. Soils at the study sites are identified as loamy, siliceous, thermic Arenic Plinthic Paleudults (Fuquay series), fine-loamy, siliceous, thermic Plinthic Paleudults (Dothan series) loamy, siliceous, thermic Grossarenic Paleudults (Troup series, Rogers 1990; United States Forest Service-Savannah River Geographic Information Systems Laboratory). Soils at the study sites reflect those associated with dry-mesic longleaf pine/wiregrass savanna (sensu Frost 1997) and fall-line subxeric longleaf pine woodland (sensu Peet \& Allard 1993) vegetation classifications.

Prior to European settlement, over $50 \%$ of the land area at SRS consisted of dry-mesic and mesic longleaf pine savanna (Frost 1997). At the time of establishment of SRS in 1950, lands within the SRS boundaries consisted primarily of forests (44\%), agricultural lands (38\%), and early successional forests (18\%) on cutover and abandoned agricultural lands (White 2005). Current activities at SRS include wildlife and forest products management, ecological restoration and research, and natural resource conservation activities (USDOE 2005). 


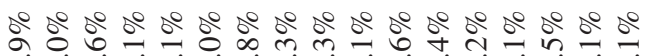

$\therefore 8$

竞

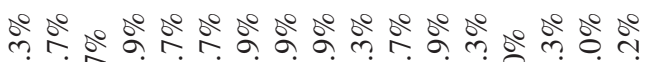

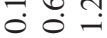

in se se

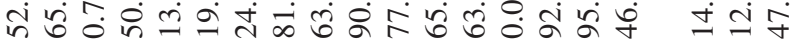

范

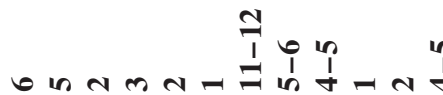
in

$\neg$ 更 $\stackrel{\circ}{\circ}$

(1)

nmamn-m+- nam-

$\stackrel{2}{\check{n}}$

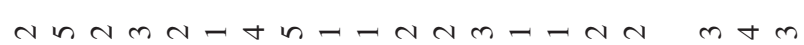

$\cong$

$\sim$

:

‡

๖ัฒ

$\stackrel{2}{5}$

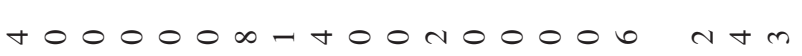

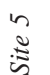

i

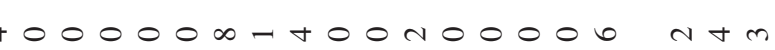

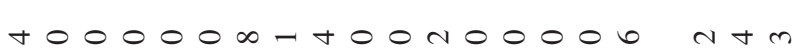

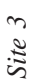

t.00000mhth00n00000 htm

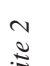

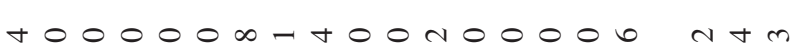

H $000000 \mathrm{H}, \mathrm{t} 0 \mathrm{n} 0000, \mathrm{htm}$ 


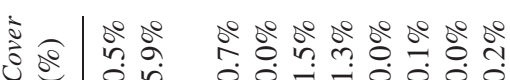
है

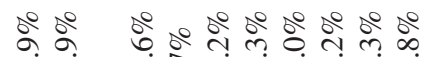
है

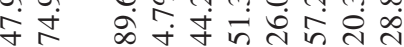

จ

a a a m in-m-a

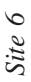

$m$ in $0-m+-0-n$

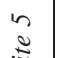

min $0-m+-0-n$

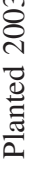

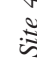

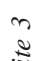

min $0-m+-0-n$ a

mi $0-m+-0-n$

$\stackrel{\sim}{\triangleq}$

min $0-m n-0-n$

ڤँ

min $0-m i n-0-n$

芒

m-aoo-omooin

$\cong$

n-aoo-omooin

$\stackrel{+}{\check{\Sigma}}$

m-aoo-omooin

m-aoonomooin

m-aoo-omooin

m- aoo-omooin

事

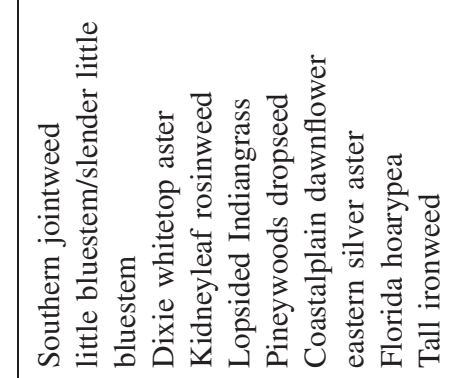

ठิ

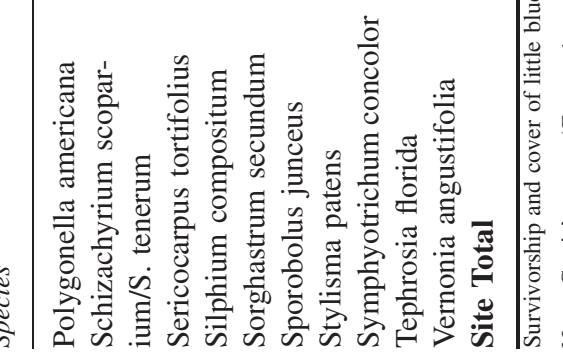


The Initial Phase of a Longleaf Pine-Wiregrass Savanna Restoration

\section{DE- AI09-00SR22188}

\section{Site Preparation and Study Design}

Site preparation prior to restoration planting consisted of thinning a $130 \times 130 \mathrm{~m}$ area within each stand with a mechanical log harvester in March 2001 to densities of 80-236 trees/ha $($ mean $=160$ trees $/$ ha, $\mathrm{SE}=21.2)$ and basal areas of $9.1-14.1 \mathrm{~m}^{2} /$ ha $\left(\right.$ mean $=12.1 \mathrm{~m}^{2} / \mathrm{ha}, \mathrm{SE}=1.0$; Table 1$)$. The resulting densities are at the low end of those typically found in remnant longleaf pine communities, whereas the resulting basal areas are similar to those found in remnant longleaf pine communities (Platt et al. 1988; Kush \& Meldahl 2000; Varner et al. 2003). In order to reduce competition from non-planted vegetation prior to planting, an herbicide mixture (5\% solution of Garlon ${ }^{\circledR} 4$ and $7.7 \mathrm{ml} / \mathrm{L}$ [1 oz/gallon] of Cide-Kick ${ }^{\circledR}$ surfactant) at a rate of $5.22-10.02 \mathrm{~L} / \mathrm{ha}(71.4-137 \mathrm{oz} / \mathrm{ac})$ was applied to a $50 \times 50 \mathrm{~m}$ area located in the center of the $130 \times 130 \mathrm{~m}$ area within each stand in June 2002. Herbicide was applied to the bark of woody species and to the foliage of woody and non-woody species with a backpack sprayer.

Within the center of the $130 \times 130 \mathrm{~m}$ area at each site, a $30 \times 30 \mathrm{~m}$ area was established to carryout intensive restoration plantings. The $30 \times 30 \mathrm{~m}$ planting area was divided into $100,3 \times 3 \mathrm{~m}$ contiguous grid cells. The 100 grid cells were established to accommodate a $2 \times 2$ factorial array of experimental treatments used to evaluate the success of the restoration plantings and to examine interactions between Aristida beyrichiana (wiregrass), a dominant grass (i.e., a "matrix" species) of the longleaf pine savanna understory, and 31 other planted species (i.e., "non-matrix species") resulting in the following treatments: wiregrass planted with non-matrix species, wiregrass planted without non-matrix species ("wiregrassonly"), non-matrix species only, and non-planted control.

Although the planting plan had called for each of the four treatments to be replicated 25 times, planting errors resulted in the following treatment replications per site: wiregrass and non-matrix species: $32-40$ cells/site $($ mean $=37$ cells/site $)$, wiregrass-only: $22-29$ cells/site $($ mean $=26$ cells/site), nonmatrix species only: $10-18$ cells/site $($ mean $=13$ cells $/ \mathrm{site})$, non-planted control: $21-28$ cells $/$ site $($ mean $=24$ cells $/ \mathrm{site})$. Treatments were randomly assigned to study the cells at each site.

Container-grown transplants of 32 herbaceous understory species were planted in July 2002 and June 2003. The species used in this experiment are common, although not restricted, to longleaf pine savanna and were chosen based on local availability. Seeds were collected from isolated populations in cemeteries, mowed powerlines and roadsides, and regularly burned plantations at SRS. Seed germination was accomplished through various techniques depending on the individual species (D. Marshall, University of Georgia, unpublished study). Germinated seeds were transferred to Hiko ${ }^{\circledR}$ propagation trays (V-93 model, 40 cells/tray, $93 \mathrm{~cm}^{3} /$ cell) containing Fafard Professional Potting Mix and grown in a greenhouse at the University of Georgia for 2-3 months. Seedlings were irrigated every $1-2$ days and fertilized with a 12-12-12 (Nitrogen-Phosphorous-Potassium) water-soluble fertilizer toward the end of greenhouse propagation. Logistical restrictions necessitated planting over a 2-year period.

\section{10-15-P}

A total of 35,056 transplants were planted at a density of $1-12$ individuals per cell, depending on the species. Wiregrass seedlings were planted at a density of five seedlings per cell. The planting density per species was based on species availability at the time of planting (Table 1). The planted location of individual transplants in each cell was not pre-determined prior to installation. Transplants were spaced $20-36 \mathrm{~cm} \mathrm{(8-14}$ in) apart, depending on local obstructions such as trees and stumps. Plantings were irrigated for 1 month after planting only if a precipitation event of $1.27 \mathrm{~cm}(0.5 \mathrm{in})$ did not occur within 1 week. For irrigation, water was pumped from a portable 3,000 gallon tank, placed adjacent to each study area, to spray spigots mounted on $1 \mathrm{~m}$ tall poles at each corner of every treatment cell. Each cell received approximately 8.4-12.6 L water $/ \mathrm{m}^{2}$ during each irrigation event. Plantings were not fertilized at any time during the study.

Long-term management of the restoration sites includes frequent burning (e.g., 1-3 year cycle) in order to maximize understory species richness (Walker \& Peet 1983, Waldrop et al. 1992, Glitzenstein et al. 2003). However, prior to the June 2006 survey, only two restoration sites have been burned since planting was completed in 2003 (Table 1). Although coordinated burning of all the restoration sites is difficult because each site exists in management units that are subject to differing natural resource management goals and protocols (e.g., red-cockaded woodpecker habitat management, plantation site preparation, etc.), two additional sites have been burned since the June 2006 survey and the remaining two unburned sites are slated to be burned over the next few years (C. Hobson 2006, USFS-Savannah River, personal communication).

\section{Plant Surveys}

All cells were surveyed in June 2004 and June 2006 for aerial percent cover of individual plant species cover and number of all planted and non-planted individuals. Species cover values below $1 \%$ (i.e., cover $<900 \mathrm{~cm}^{2}$ ) were estimated to the nearest $1,0.5,0.25,0.125$, or $0.0625 \%$, whereas species cover above $1 \%$ were estimated to the nearest whole percent. Due to the difficulty in differentiating Schizachyrium scoparium (little bluestem) from S. tenerum (slender little bluestem) and Liatris elegans (pinkscale blazing star) juveniles from $L$. secunda (piedmont blazing star) juveniles, these congeneric species are combined for all data analyses. Vegetative cover of individual planted species and community responses to restoration plantings including species richness, diversity, evenness, and total vegetative cover are derived from June 2006 data. In the anal yses of community responses to restoration plantings, "restored cells" include both treatments where non-matrix species are planted with and without wiregrass, whereas "control cells" include the non-planted treatment and the wiregrass-only treatment.

To assess the effect of restoration plantings on ecosystem productivity without destructive sampling, we used visual estimates of vegetative cover and measures of canopy light interception as surrogates for aboveground production. Interception 


\section{DE- AI09-00SR22188 JOURNAL ARTICLE $2010 \quad$ 10-15-P}

of photosynthetically active radiation (PAR interception) by the understory herbaceous layer was measured using an AccuPAR PAR/LAI ceptometer (Decagon, Pullman, WA, U.S.A). Measurements were taken above the herb layer and at ground level in each cell in October 2006 within 2 hours of solar noon. Herb layer PAR interception was expressed as percentage of PAR reaching the ground [(1-(PAR below herb layer/PAR above herb layer) $) \times 100$ ]. Herb layer PAR interception was not determined for site six because a prescribed burn in September 2006 had significantly reduced understory vegetative cover.

\section{Data Analysis}

Initial survival (i.e., 1-2 years post-transplanting) per planted cell was calculated for all planted species by dividing the number of individuals per cell present in June 2004 by the total number of individuals originally planted (Table 1). Because it could not be determined whether individuals present in June 2006 were survivors from the original plantings or the result of recruitment, survival data to June 2006 were not calculated for non-matrix species. However, we were able to calculate survival to 2006 (i.e., 3 years post-transplanting) for wiregrass because wiregrass recruitment did not occur after transplanting, thereby negating any problems differentiating between recruitment and survival.

Differences in the survival of non-matrix species across all sites, differences between planted and non-planted species cover in aggregate between restored and control cells across all sites, and differences in non-planted species cover in aggregate, total and non-planted species richness, total vegetative cover, and PAR interception by the herb layer between restored and control cells across all sites were tested with two-way analyses of variance (ANOVA). In these analyses, treatments (i.e., the presence or absence of matrix and non-matrix species) were fixed effects with site as a random block. Interactions between treatments were not significant for any test, thus analyses reported here tested only for treatments as main effects. Nonparametric tests were used for analyses where data did not meet assumptions of normality or homogeneity of variance (Sokal \& Rolf 1995), despite transformations including square root, arcsine square root, $\log$, and $\log (x+1)$. Differences across all sites in survival and cover of individual species, survival and cover of wiregrass, wiregrass survival between "wiregrass only" cells and cells where wiregrass had been planted with non-matrix species, total species richness, Shannon's Diversity ( $H^{\prime}$; Magurran 1988$)$, and community evenness $\left(H^{\prime} / H_{\mathrm{Max}}\right.$; Magurran 1988) were tested using a Kruskal-Wallis one-way ANOVA by ranks $\left(\chi^{2}\right)$. A Mann-Whitney $U$ test was used to test for differences in wiregrass cover between "wiregrass only" cells and cells where wiregrass had been planted with non-matrix species, and Shannon's Diversity and community evenness between restored and control cells. We also calculated Simpson's diversity, but because findings did not differ, we report only Shannon's Diversity. We used Spearman's Rank Correlation to test for relationships between the number of individuals per species planted and individual species cover and survival. Significance level was set at $\alpha=0.050$ for all analyses. All statistical analyses were conducted using SPSS release 14.0.0 (SPSS, Inc. 2005).

\section{Results \\ Plant Survival}

Non-matrix Species. Of the 34,125 seedlings of nonmatrix species transplanted in 2002 and 2003 across the entire study site, 25,689 , or $75 \%$, were still alive in June 2004. Mean survival per cell differed among individual species across all sites $\left(\chi^{2}=153.32, p<0.001, d f=29\right)$. Averaged across all sites, mean survival per species was $47.6 \%$ $(\mathrm{SE}=0.4)$. Lespedeza hirta (hairy lespedeza), a perennial legume, exhibited the greatest overall survival per cell at 95\% ( $\mathrm{SE}=1.1$ ), whereas Aristida purpurascens (arrowfeather threeawn), a perennial grass, exhibited the lowest survival at $0.7 \%(\mathrm{SE}=0.5$; Table 1$)$. A significant correlation did not exist between the number of individuals planted per species and individual species survival (Spearman's $r=0.160$, $p=0.399$ ).

Wiregrass. Of the 1,931 wiregrass seedlings planted across all sites, 1,286, or $67 \%$, survived to 2004. In 2006, 1,257 wiregrass plants remained alive, which indicates very little mortality between 2004 and 2006 (2\%). Wiregrass survival per cell to 2006 was significantly lower in cells where it had been planted with non-matrix species than in cells were it had been planted alone across all sites (mean with non-matrix $=54.3 \%, \mathrm{SE}=2.3$ vs. mean without non-matrix $=80.6 \%$, $\mathrm{SE}=2.8 ; U=10,968, n=378, p<0.001)$.

\section{Species Abundances}

Mean cover per cell in 2006 differed among individual species across all sites $\left(\chi^{2}=147.157, p<0.001, d f=29\right)$. Averaged across all sites, little bluestem exhibited the greatest mean cover per cell at $5.9 \%(\mathrm{SE}=0.80)$ followed by hairy lespedeza and wire grass at $2.0 \%(\mathrm{SE}=0.09)$. Several species exhibited cover of much $<1.0 \%$ (Table 1). A positive correlation existed between the number of individuals planted per species and individual species cover (Spearman's $r=0.550, p=0.002$ ).

Mean cover of wiregrass per cell in 2006 was significantly lower in cells where it had been planted with non-matrix species than in cells were it had been planted alone across all sites (mean with non-matrix $=1.4 \%, \mathrm{SE}=0.10$ vs. mean without non-matrix $=2.9 \%, \mathrm{SE}=0.16 ; U=9269.5, n=$ $378, p<0.001)$.

The mean aggregate cover per cell of planted species in 2006 was significantly greater in restored cells compared to control cells across all sites (restored mean $=25.9 \%, \mathrm{SE}=$ 0.85 vs. control mean $=7.8 \%, \mathrm{SE}=0.66 ; F=290.178, d f$ $=1,592, p<0.001$; Figure 1). The mean aggregate cover per cell of resident, non-planted species in 2006 did not vary significantly between restored and control cells $(F=0.120$, $d f=1,592, p=0.730)$. Within restored cells, aggregate 
The Initial Phase of a Longleaf Pine-Wiregrass Savanna Restoration

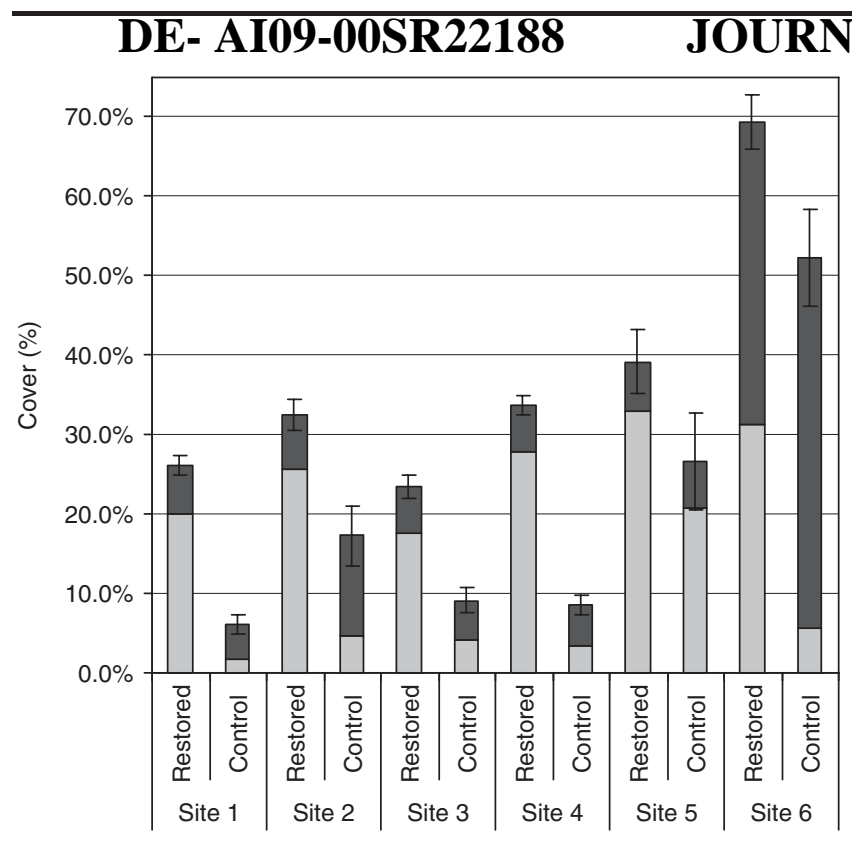

$\square$ Non-planted Species

$\square$ Planted Species

Figure 1. Total vegetative cover ( $\pm 1 \mathrm{SE})$ among sites, including the relative contribution of planted and non-planted species, between restored and control plots in spring 2006. Planted species cover was significantly greater $(p<0.001)$ in restored cells compared to control cells across all sites and was significantly greater $(p<0.001)$ than non-planted cover in restored cells across all sites.

cover of planted species was significantly greater than that of the resident, non-planted species in 2006 across all sites $(F=163.136, d f=1,593, p<0.001$; Figure 1$)$.

\section{Community Diversity}

Total species richness (SR), Shannon's Diversity $\left(H^{\prime}\right)$, and community evenness $(E)$ calculated for 2006 were significantly greater in restored cells compared to control cells across all sites ( $\mathrm{SR}$ : restored mean $=30.35, \mathrm{SE}=0.287$, control mean $=12.33, \mathrm{SE}=0.342 ; U=991.0, n=600, p<$ $0.001 ; H^{\prime}$ : restored mean $=2.87, \mathrm{SE}=0.016$, control mean $=1.87, \mathrm{SE}=0.032 ; U=2768.5, n=600, p<0.001 ; E$ : restored mean $=0.845, \mathrm{SE}=0.004$, control mean $=0.781$, $\mathrm{SE}=0.008 ; U=31534.0, n=600, p<0.001)$. Non-planted species richness was greater in restored cells compared to control cells (mean $=8.82$ spp., $\mathrm{SE}=0.301$ vs. mean $=7.51$ spp., $\mathrm{SE}=0.281$, respectively) across all sites $(F=15.056$, $d f=1,592, p<0.001)$.

\section{Productivity}

Total vegetative cover per cell in spring 2006 was significantly greater in the restored cells compared to control cells (mean $=37.4 \%, \mathrm{SE}=1.3$ vs. mean $=19.9 \%, \mathrm{SE}=1.4$, respectively) across all sites ( $F=129.962, d f=1,592, p<0.001$; Figure 1). Consistent with the findings for total vegetative cover, PAR interception by the herb layer per cell was greater

2010 10-15-P

in restored compared to control cells (mean $=28.1 \%, \mathrm{SE}=$ 1.6 vs. mean $=12.8 \% \mathrm{SE}=1.7$, respectively) across all sites.

\section{Discussion \\ Species Establishment}

Across all sites, the average survival of planted seedlings per species was relatively high at $48 \%$. Harrington et al. (2003) found that 1-year survival of transplanted species averaged approximately $75 \%$ under normal soil moisture conditions, but plummeted to $6 \%$ when seedlings were planted under extremely dry soil conditions. Although results on the survival of individual species are mixed, it is promising that individuals of all planted species were alive in 2006.

Wiregrass survival and cover was significantly reduced when planted with other species indicating a competitive effect of non-matrix species on wiregrass growth and establishment. Although this reduction in wiregrass survival and growth has obvious direct impacts on its reestablishment, it is important to note that wiregrass was not competitively excluded by non-matrix species. In fact, wiregrass cover increased between 2004 and 2006 when planted with non-matrix species (data not shown). Therefore, wiregrass populations can be reestablished in the presence of other species, however, if wiregrass establishment is the primary restoration goal; it may be advisable to reestablish wiregrass populations prior to the reintroduction of non-matrix species.

Wiregrass survival in this experiment was generally lower or similar to results from other studies investigating the restoration of wiregrass populations. Glitzenstein et al. (2001) observed greater overall wiregrass survival after 1 year compared to this study. Lower survival in dry sites was attributed to increased moisture stress during initial establishment compounded with site burning soon after transplanting. Conversely, burning did not appear to negatively affect wiregrass in this experiment. Two of the study sites had been burned in February 2 years after transplanting, however, mean survival after 3 years in wiregrass-only cells at these sites was approximately $80 \%$. Mulligan et al. (2002) also noted wiregrass survival of approximately $80 \%$ after 4 years in plots that had been burned in June soon after transplanting.

Compared to previous investigations of wiregrass reestablishment at SRS (Outcalt et al. 1999), survival in wiregrassonly cells in our study was higher even though our planting protocol resulted in a higher planting density. Mulligan et al. (2002) also found equivalent wiregrass survival at higher planting densities. Conversely, the higher density plantings of wiregrass in this experiment may have affected foliar growth. Outcalt et al. (1999) observed that the area of individual wiregrass seedlings after 3 years of growth averaged $3,540 \mathrm{~cm}^{2}$, whereas the area of individual wiregrass plants in wiregrassonly cells in this experiment averaged $636 \mathrm{~cm}^{2}$.

\section{Community Diversity}

The restoration plantings significantly increased plant community species richness, diversity and evenness. Again, however, 


\section{DE- AI09-00SR22188 JOURNAL ARTICLE $2010 \quad$ 10-15-P}

the diversity of these plantings is still generally lower than found in naturally occurring longleaf pine-wiregrass communities. At the site level, Kush et al. (1999) observed greater species richness in a fire-maintained second growth longleaf pine forest compared to this study. Similarly, Cox et al. (2004) also observed greater species richness in the control plots of a restoration experiment compared to the control cells in this study. At the cell level, our results (mean $=30.4 \mathrm{spp}$. in restored cells) are most similar to results by Kirkman et al. (2001), which found $28 \mathrm{spp} . / 10 \mathrm{~m}^{2}$ under a similar soil moisture regime in a longleaf pine-wiregrass savanna in Georgia.

Naturally occurring longleaf pine-wiregrass communities generally exhibit greater species richness, diversity and evenness than observed in this study. Considering that the restored communities in our experiment have been developing for only 4 years, it is not surprising that the community variables observed here are lower than in the remnant areas. However, in a few instances, the values observed in our experiment were actually greater than those found in other studies of pine-wiregrass communities. Maliakal et al. (2000) found that species richness ranged from 18 to 31 species in a fire-maintained (i.e., fire frequency of 1-5 years) wiregrass flatwoods, whereas Rodgers and Provencher (1999) found an average of $83 \mathrm{spp} . / 1,600 \mathrm{~m}^{2}$ in wiregrass-dominant longleaf pine sandhill community. In a study of remnant longleaf pine communities at SRS, Duncan and Peet (1996) found that species richness ranged between 69 and 83 species in $1,000 \mathrm{~m}^{2}$ cells. These results are promising considering that in our study, site-level species richness averaged 91 species, even though the size of our sampling area was smaller compared to these other studies.

\section{Productivity}

High rates of survival and growth for many of the planted species led to greater total vegetative cover and light interception in restored cells compared to control cells indicating a positive impact of restoration plantings on plant productivity. Increased vegetative cover in restored cells is largely due to planted species cover, rather than non-planted species cover (Figure 1). The contribution to vegetative cover by planted species in control cells also indicates the positive impact restoration plantings have on productivity. Planted species cover in control cells also provides evidence of successful dispersal and colonization by planted species - a very important component of successful landscape-scale restoration.

As with other plant community variables presented here, vegetative cover was generally lower than observed in naturally occurring longleaf pine ecosystems or other restoration studies. Hedman et al. (2000) found greater mean understorey vegetative cover at $60 \%$ in similar sized plots $\left(10 \mathrm{~m}^{2}\right)$ in a second growth longleaf pine forest compared to the $37 \%$ average in restored cells observed here.

\section{Conclusion}

Initial results suggest that the restoration plantings have successfully increased local diversity and productivity compared to non-restored areas. In general, transplanted seedlings exhibited good initial survival after planting, and individuals of all species were encountered in 2006 surveys. Survival of wiregrass seedlings was higher in this study compared to similar studies. Wiregrass survival and cover were significantly reduced when planted with other species compared to when planted alone indicating a competitive effect of non-matrix species on wiregrass growth and establishment. Future work will examine the biotic interactions between wiregrass and other planted and non-planted species in the light of differing edaphic conditions and disturbance regimes and will also document the dispersal of planted species into the surrounding landscape.

The initial results of our long-term and landscape-scale experiment indicating successful establishment of wiregrass and other native savanna species represent an important first step in restoring these ecosystems to their natural condition in a degraded landscape. Intensive site preparation including overstory thinning and herbiciding prior to planting followed by irrigation and the application of prescribed fire after planting are likely attributed to high survival and growth of transplanted species at SRS. Introducing native propagules to degraded areas such as longleaf pine plantations, in conjunction with site preparation and maintenance, may help reverse the loss of the longleaf pine-wiregrass ecosystem in the southeastern United States.

\section{Acknowledgments}

The authors gratefully acknowledge the assistance of Ellen Damschen, Nick Drozda, Laura Krysinski, Todd Kuntz, Brett Miley, Kim Nayda, Tona Segar, Marie Smith, and Erin Questad in data collection and Chris Hobson in fire management of the restoration sites. The authors would like to especially thank Doug Marshall for his assistance in plant propagation. This research was funded by USDA Cooperative Agreement \#04-CS-11083601-008 and supported by the Department of Energy - Savannah River Operations Office through the U.S. Forest Service-Savannah River under Interagency Agreement DE-AI09-00SR22188.

\section{Implications for Practice}

- Multi-species plantings in a degraded landscape have positive impacts on community diversity and vegetative cover.

- Intensive site preparation including overstory thinning and herbiciding prior to planting followed by irrigation may help in the establishment of target species.

- Survival and growth of wiregrass was greater when planted in the absence of non-matrix species suggesting that wiregrass establishment may be enhanced by planting in monocultures rather than in multi-species assemblages. 
The Initial Phase of a Longleaf Pine-Wiregrass Savanna Restoration

\section{DE- AI09-00SR22188 \\ JOURNAL ARTICLE

2010 \\ 10-15-P}

\section{LITERATURE CITED}

Bell, S. S., M. S. Fonseca, and L. B. Motten. 1997. Linking restoration and landscape ecology. Restoration Ecology 5:318-325.

Buhlmann, K. A., T. D. Tuberville, Y. Leiden, T. J. Ryan, S. Poppy, C. T. Winne, J. L. Greene, T. M. Mills, D. E. Scott, and J. W. Gibbons. 2005. Biotic communities: Amphibians and reptiles. Pages 203-223 in J. C. Kilgo and J. I. Blake, editors. Ecology and management of a forested landscape: fifty years on the Savannah River Site. Island Press, Washington, DC.

Clewell, A. F. 1989. Natural history of wiregrass (Aristida stricta Michx., Gramineae). Natural Areas Journal 9:223-233.

Cox, A. C., D. R. Gordon, J. L. Slapcinsky, G. S. Seamon. 2004. Understory restoration in longleaf pine sandhills. Natural Areas Journal 24:4-14.

Duever, L. C. 1989. Research priorities for the preservation, management, and restoration of wiregrass ecosystems. Natural Areas Journal 9:214-218.

Duncan, R. P., and R. K. Peet. 1996. A template for reconstructing the natural, fire dependent vegetation of the fall-line sandhills, south-eastern United States. Report 96-23-R, USDA Forest Service, Savannah River Institute, Aiken, South Carolina, 32.

Foster, B. L. 2001. Constraints on colonization and species richness along a grassland productivity gradient: the role of propagule availability. Ecology Letters 4:530-535.

Frost, C. C. 1993. Four centuries of changing landscape pattern in the longleaf pine ecosystem. Pages $17-43$ in S. M. Hermann, editor. Proceedings of the 18th Tall Timbers Fire Ecology Conference, The Longleaf Pine Ecosystem: Ecology, Restoration and Management. Tall Timbers Research, Inc., Tallahassee, Florida.

Frost, C. C. 1997. Presettlement vegetation and natural fire regimes of the Savannah River Site. Report 97-10-R, USDA Forest Service, Savannah River Forest Station, New Ellenton, South Carolina, 179.

Glitzenstein, J. S., D. R. Streng, and D. D. Wade. 2003. Fire frequency effects on longleaf pine (Pinus palustris P. Miller) vegetation in South Carolina and northeast Florida, USA. Natural Areas Journal 23:22-37.

Glitzenstein, J. S., D. R. Streng, D. D. Wade, J. Brubaker. 2001. Starting new populations of longleaf pine ground-layer plants in the Outer Coastal Plain of South Carolina, USA. Natural Areas Journal 21:89-110.

Harcombe, P. A., J. S. Glitzenstein, R. G. Knox, S. L. Orzell, and E. L. Bridges. 1993. Vegetation of the longleaf pine region of the West Gulf Coastal Plain. Pages 83-104 in S. M. Hermann, editor. Proceedings of the 18th Tall Timbers Fire Ecology Conference, The longleaf pine ecosystem: ecology, restoration and management. Tall Timbers Research, Inc., Tallahassee, Florida.

Hardin, E. D., and D. L. White. 1989. Rare vascular plant taxa associated with wiregrass (Aristida stricta) in the southeastern United States. Natural Areas Journal 9:234-244.

Harrington, T. B., C. M. Dagley, and M. B. Edwards. 2003. Above- and belowground competition from longleaf pine plantations limits performance of reintroduced herbaceous species. Forest Science 49:681-695.

Harrington, T. B., and M. B. Edwards. 1999. Understory vegetation, resource availability, and litterfall response to pine thinning and woody vegetation control in longleaf pine plantations. Canadian Journal of Forest Research 29:1055-1064.

Hedman, C. W., S. L. Grace, and S. E. King. 2000. Vegetation composition and structure of southern coastal plain pine forest: An ecological comparison. Forest Ecology and Management 134:233-247.

Johnston, P. A. 2005. Threatened and endangered species: red-cockaded woodpecker. Pages 301-312 in J. C. Kilgo and J. I. Blake, editors. Ecology and management of a forested landscape: fifty years on the Savannah River Site. Island Press, Washington, DC.

Kirkman, L. K., R. J. Mitchell, R. C. Helton, and M. B. Drew. 2001. Productivity and species richness across an environmental gradient in a fire-dependent ecosystem. American Journal of Botany 88:2119-2128.

Kush, J. S., and R. S. Meldahl. 2000. Composition of a virgin stand of longleaf pine in South Alabama. Castanea 65:56-63.
Kush, J. S., R. S. Meldahl, and W. D. Boyer. 1999. Understory plant community response after 23 years of hardwood control treatments in natural longleaf pine (Pinus palustris) forests. Canadian Journal of Forest Research 29:1047-1054.

Magurran, A. E. 1988. Ecological diversity and its measurement. Princeton University Press, Princeton, New Jersey.

Maliakal, S. K., E. S. Menges, and J. S. Denslow. 2000. Community composition and regeneration of Lake Wales Ridge wiregrass flatwoods in relation to time-since fire. Journal of the Torrey Botanical Society 127:125-138.

Markewitz, D., F. Sartori, and C. Craft. 2002. Soil change and carbon storage in longleaf pine stands planted on marginal agricultural lands. Ecological Applications 12:1276-1285.

McKee, W. H. 1982. Changes in soil fertility following prescribed burning on Coastal Plain pine sites. Research Paper SE-234, USDA Forest Service, Southeastern Forest Experiment Station, Asheville, North Carolina, 23.

Mitchell, R. J., L. K. Kirkman, S. D. Pecot, C. A. Wilson, B. J. Palik, and L. R. Boring. 1999. Patterns and controls of ecosystem function in longleaf pine-wiregrass savannahs. I. Aboveground net primary productivity. Canadian Journal of Forest Research 29:743-751.

Means, D. B. 1996. Longleaf pine forest, going, going, . . . Pages 210-229 in M. B. Davis, editor. Eastern old-growth forests: prospects for rediscovery and recovery. Island Press, Washington, DC.

Mulligan, M. K., L. K. Kirkman, and R. J. Mitchell. 2002. Aristida beyrichiana (wiregrass) establishment and recruitment: implications for restoration. Restoration Ecology 10:68-76.

Noss, R. F. 1989. Longleaf pine and wiregrass: Keystone components of an endangered ecosystem. Natural Areas Journal 9:211-213.

Noss, R. F., E. T. LaRoe III, and J. M. Scott. 1995. Endangered ecosystems of the United States: a preliminary assessment of loss and degradation. Biological Report 28. U.S. Dept. of Interior, National Biological Service, Washington, DC, 58.

Outcalt, K. W. 1994. Seed production of wiregrass in central Florida following growing season prescribed burns. International Journal of Wildland Fire 4:123-125.

Outcalt, K. W., and R. M. Sheffield. 1996. The longleaf pine forest: Trends and current conditions. Resource Bulletin SRS-9. USDA Forest Service, Southern Research Station, Asheville, North Carolina, 23.

Outcalt, K. W., M. E. Williams, and O. Onokpise. 1999. Restoring Aristida stricta to Pinus palustris ecosystems on the Atlantic Coastal Plain, USA. Restoration Ecology 7:262-270.

Peet, R. K., and D. J. Allard. 1993. Longleaf pine vegetation of the Southern Atlantic and Eastern Gulf Coast Regions: a preliminary classification. Pages $45-81$ in S. M. Hermann, editor. Proceedings of the 18th Tall Timbers Fire Ecology Conference, The longleaf pine ecosystem: ecology, restoration and management. Tall Timbers Research, Inc., Tallahassee, Florida.

Platt, W. J., S. M. Carr, M. Reilly, and J. Fahr. 2006. Pine savanna overstorey influences on ground-cover biodiversity. Applied Vegetation Science 9:37-50.

Platt, W. J., G. W. Evans, and M. M. Davis. 1988. Effects of fire season on flowering of forbs and shrubs in longleaf pine forests. Oecologia 76:353-363.

Platt, W. J., J. S. Glitzenstein, and D. R. Streng. 1989. Evaluating pyrogenicity and its effects on vegetation in longleaf pine savannas. Pages $143-163$ in S. M. Hermann, editor. Proceedings of the 17th Tall Timbers Fire Ecology Conference, High intensity fire in wildlands: management challenges and options. Tall Timbers Research Station, Tallahassee, Florida.

Reinhart, K. O., and E. S. Menges. 2004. Effects of reintroducing fire to a central Florida sandhill community. Applied Vegetation Science $7: 141-150$

Rodgers, H. L., and L. Provencher. 1999. Analysis of longleaf pine sandhill vegetation in northwest Florida. Castanea 64:138-162.

Rogers, V. A. 1990. Soil survey of Savannah River Plant Area, parts of Aiken, Barnwell, and Allendale Counties, South Carolina. USDA Soil Conservation Service, Washington, DC. 


\section{DE- AI09-00SR22188 JOURNAL ARTICLE $2010 \quad 10-15-P$}

Sokal, R. R., and F. J. Rolf. 1995. Biometry: the principals and practice of statistics in biological research. $3^{\text {rd }}$ edition. W.H. Freeman and Company, New York.

SPSS, Inc. 2005. SPSS: release 14.0.0 for Windows. SPSS, Inc., Chicago, Illinois.

Suding, K. N., K. L. Gross, and G. R. Houseman. 2004. Alternative states and positive feedbacks in restoration ecology. Trends in Ecology \& Evolution 19:46-53.

U.S. Department of Energy (USDOE). 2005. Natural Resource Management Plan for the Savannah River Site. Savannah River Site, New Ellenton, South Carolina.

Van Lear, D. H., W. D. Carroll, P. R. Kapeluck, R. Johnson. 2005. History and restoration of the longleaf pine-grassland ecosystem: implications for species at risk. Forest ecology and Management 211:150-165.

Varner, J. M. III, J. S. Kush, and R. S. Meldahl. 2003. Vegetation of frequently burned old growth longleaf pine (Pinus palustris Mill.) savannas on Choccolocco Mountain, Alabama, USA. Natural Areas Journal 23:43-52.

Wade, D. D., and J. Lundsford. 1990. Fire as a forest management tool: Prescribed burning in the southern United States. Unasylva 162:28-38.

Waldrop, T. A., D. L. White, and S. M. Jones. 1992. Fire regimes for pinegrassland communities in the southeastern United States. Forest Ecology and Management 47:195-210.
Walker, J. 1993. Rare vascular plant taxa associated with the longleaf pine ecosystems. Pages $105-125$ in S. M. Hermann, editor. Proceedings of the 18th Tall Timbers Fire Ecology Conference, The longleaf pine ecosystem: ecology, restoration and management. Tall Timbers Research, Inc., Tallahassee, Florida.

Walker, J., and R. K. Peet. 1983. Composition and species diversity of pine-wiregrass savannas of the Green Swamp, North Carolina. Vegetatio 55:163-179.

Ware, S., C. C. Frost, and P. D. Doerr. 1993. Southern mixed hardwood forest: the former longleaf pine forest. Pages 447-493 in W. H. Martin, S. G. Boyce, and A. C. Echternacht, editors. Biodiversity of the southeastern United States: lowland terrestrial communities. Wiley, New York.

White, D. L. 2005. The Savannah River Site, past and present: land use history. Pages $1-12$ in J. C. Kilgo, and J. I. Blake, editors. Ecology and management of a forested landscape: Fifty years on the Savannah River Site. Island Press, Washington, DC.

Zedler, J. B. 1996. Coastal mitigation in Southern California: the need for a regional restoration strategy. Ecological Applications 6:83-94.

Zobel, M. 1997. The relative role of species pools in determining plant species richness: an alternative explanation of species coexistence. Trends in Ecology \& Evolution 12:266-269. 